\title{
Parachloroidium gen. nov. (Trebouxiophyceae, Chlorophyta), a novel genus of coccoid green algae from subaerial corticolous biofilms
}

\author{
JiŘí Neustupa*, Yvonne Němcová, Jana Veselá, Jana Steinová and Pavel Škaloud \\ Department of Botany, Faculty of Science, Charles University of Prague, Benátská 2, Praha 2, 128 01, Czech Republic
}

\begin{abstract}
Neustupa J., Němcová Y., Veselá J., Steinová J. and Škaloud P. 2013. Parachloroidium gen. nov. (Trebouxiophyceae, Chlorophyta), a novel genus of coccoid green algae from subaerial corticolous biofilms. Phycologia 52: 411-421. DOI: 10 . $2216 / 13-142.2$
\end{abstract}

\begin{abstract}
The Watanabea clade of the Trebouxiophyceae included mostly unicellular coccoid microalgae that thrived in various terrestrial microhabitats. The diversity of these morphologically uniform microalgae was little known, and several new genus-level lineages had recently been described on the basis of molecular data. In this study, we provided a taxonomic description of a new trebouxiophycean genus, Parachloroidium, found in the Mediterranean in corticolous phototrophic biofilms. Their simple chlorelloid morphology did not unambiguously distinguish the Parachloroidium strains from other similar green algae. However, ultrastructural characteristics and molecular phylogenetic analyses based on the $18 \mathrm{~S}$ ribosomal (r)DNA, internal transcribed spacer region (ITS) and the chloroplast ribulose-bisphosphate carboxylase gene sequences provided a basis for the discrimination of Parachloroidium from related genera of the Watanabea clade. The four strains investigated formed two species, $P$. laureanum and $P$. lobatum, which differed in plastid morphology and in ITS and $18 \mathrm{~S}$ rDNA sequences. All four strains were characterized by globular or ellipsoidal cell shapes, single parietal plastids and asexual reproduction by autospores. Their plastids lacked typical pyrenoids; however, plastids included peculiar thylakoid-free regions of irregular shape. On the basis of accumulating molecular data, we concluded that the Watanabea clade was a diverse phylogenetic lineage within the subaerial chlorelloid green algae.
\end{abstract}

Key Words: Green algae, Subaerial algae, Taxonomy, Trebouxiophyceae, Watanabea clade

\section{INTRODUCTION}

The so-called Watanabea clade was defined by Karsten et al. (2005) as a monophyletic lineage of the Trebouxiophyceae that includes the type strain SAG 211-9b of Watanabea reniformis N. Hanagata, Karube, Chihara, \& P.C. Silva, and a group of Chlorella-like strains that were formally included by Darienko et al. (2010) in the genus Chloroidium Nadson. Additional studies on molecular phylogeny of trebouxiophytes showed that the Watanabea clade includes other microalgal genera, such as Viridiella P. Albertano, Pollio, \& Taddei, Heterochlorella Neustupa, Němcová, Eliáš, \& Škaloud, Heveochlorella J. Zhang, V.A.R. Huss, X. Sun, K. Chang, \& D. Pang, Kalinella Neustupa, Němcová, Eliáš, \& Škaloud and Phyllosiphon Kühn (Huss et al. 2002; Zhang et al. 2008; Neustupa et al. 2009, 2013; Ma et al. 2013). Most of these taxa are Chlorella-like coccoid autosporine microalgae that thrive in various subaerial and freshwater habitats, but the genus Phyllosiphon, which is characterized by a siphonous habit, is known as a parasite of vascular plants (Aboal \& Werner 2011). However, sequences corresponding to this lineage were recently also reported from epilithic biofilms (Hallmann et al. 2013). Because of their relatively uniform morphology, most of the coccoid taxa were only recognized by molecular methods. Recent molecular data from studies that used environmental sequencing and the sequencing of various strains deposited in culture collections revealed that several taxa of this clade, such as Heterochlorella luteoviridis and species within the

\footnotetext{
* Corresponding author (neustupa@natur.cuni.cz).
}

genus Chloroidium, are probably relatively widely distributed, and frequently occur in subaerial and freshwater phytobenthic microbial biofilms (Darienko et al. 2010; Hallmann et al. 2011; Lee \& Hur 2012). Conversely, four species of the genera Kalinella and Heveochlorella J. Zhang, V.A.R. Huss, X. Sun, K. Chang, \& D. Pang have so far been only reported from the type localities in corticolous subaerial microhabitats of subtropical and tropical ecosystems (Zhang et al. 2008; Neustupa et al. 2009, 2013; Ma et al. 2013). In addition, several taxonomically undetermined $18 \mathrm{~S}$ ribosomal (r)DNA sequences that probably represent undescribed taxa of the Watanabea clade were deposited in GenBank. These include the sequence AM260450 that originated from photobiont cells of the lichen Psoroglaena epiphylla Lücking (Nyati et al. 2007) and the sequences AB058305 and AB006045 from unidentified Chlorella-like strains. These records indicate that the taxonomic diversity of the Watanabea clade could be considerably higher than previously believed, and that this phylogenetic lineage may actually include several Chlorella-like microalgae that frequently occur in subaerial biofilms. In this study, we present a taxonomic description of Parachloroidium, a new genus of the Watanabea clade, according to the International Code of Nomenclature for Algae, Fungi and Plants. A combination of morphological observations and molecular phylogenetic analyses was used to characterize this previously unknown lineage of trebouxiophycean chlorelloid microalgae, which was discovered in phototrophic corticolous biofilms in Mediterranean Europe.

Besides various phenotypic and phylogenetic data the compensatory base changes (CBCs) in the secondary structure 
model of the second part of the internal transcribed spacer (ITS2) were also used for species delimitation (Müller et al. 2007; Bock et al. 2011). Previous studies illustrated that occurrence of $\mathrm{CBCs}$ in the conserved regions of helices II and III of the ITS2 models of two closely related taxa are highly correlated with their sexual incompatibility (Müller et al. 2007; Coleman 2009). Consequently, CBCs in the abovementioned parts of the ITS2 secondary structure model may be used as an auxiliary feature for species discrimination even in tentatively asexual organisms, such as many subaerial coccoid green algae.

\section{MATERIAL AND METHODS}

The algal strains were isolated from samples of corticolous microbial biofilms taken from three trees growing in different European locations. Strain CAUP H8501 was obtained from the bark of Laurus nobilis Linnaeus growing

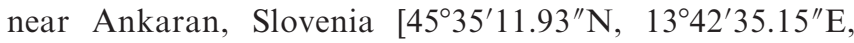
altitude $5 \mathrm{~m}$ above sea level (asl)]. Two strains, CAUP H8502 and I6e, were isolated from the bark of Fraxinus ornus Linnaeus growing near Pacug, Slovenia $\left(45^{\circ} 31^{\prime} 33.55^{\prime \prime} \mathrm{N}, 13^{\circ} 35^{\prime} 40.95^{\prime \prime} \mathrm{E}\right.$, altitude $55 \mathrm{~m}$ asl). Finally, strain CAUP H8503 was isolated from the corticolous biofilm of Ficus carica var. caprificus (Risso) Tschirch \& Ravasini in Policoro, Italy $\left(40^{\circ} 10^{\prime} 35.75^{\prime \prime} \mathrm{N}, 16^{\circ} 41^{\prime} 49.71^{\prime \prime} \mathrm{E}\right.$, altitude $10 \mathrm{~m}$ asl). Each of the four strains was isolated from a sample of approximately $1 \mathrm{~cm}^{2}$ of bark surface that was taken from the shaded north face of the tree trunk, at 120 $150 \mathrm{~cm}$ above the soil surface. The strains are available from the Culture Collection of Algae of Charles University in Prague (CAUP; http://botany.natur.cuni.cz/algo/caup. html). For this study, the strains were cultivated on agarsolidified Bold's basal medium (Andersen et al. 2005) at $24^{\circ} \mathrm{C}$, with illumination of $40 \mu \mathrm{mol} \mathrm{m} \mathrm{m}^{-2} \mathrm{~s}^{-1}$ provided by 18 W cool fluorescent tubes (Philips TLD 18W/33).

Using differential interference contrast photomicrographs of cells were taken with an Olympus BX51 light microscope and an Olympus Z5060 camera (Olympus Corporation, Tokyo, Japan). For transmission electron microscopy, samples of each strain were fixed for $2 \mathrm{~h}$ at $5 \mu \mathrm{C}$ in $2 \%$ glutaraldehyde in $0.05 \mathrm{M}$ phosphate buffer, and postfixed for $2 \mathrm{~h}$ in $1 \%$ osmium tetroxide in $0.05 \mathrm{M}$ phosphate buffer and, subsequently, for $12 \mathrm{~h}$ at $5 \mu \mathrm{C}$ in $1 \%$ uranyl acetate solution. Then, the samples were dehydrated through an ethanol series and embedded in Spurr's medium via propylene oxide. Ultrathin sections, cut with a diamond knife on an Ultracut E (Leica Microsystems GmbH, Wetzlar, Germany), were poststained with lead citrate and examined using a JEOL 1011 transmission electron microscope (JEOL Ltd, Tokyo, Japan).

Total genomic DNA was isolated using the InstaGene matrix (Bio-Rad, Hercules, California, USA) as described by Škaloud et al. (2012). Sequences of the 18S rDNA, the ITS region, and the chloroplast ribulose-bisphosphate carboxylase gene $(r b c \mathrm{~L})$ were obtained by polymerase chain reaction (PCR) amplification using an XP thermal cycler (Bioer, Tokyo, Japan). Each 20- $\mu$ l PCR reaction contained $13.1 \mu \mathrm{l}$ of sterile Milli-Q water (Millipore Corp., Billerica, Massachusetts, USA), $2 \mu$ of AmpliTaq Gold ${ }^{\circledR} 360$ buffer 10X
(Life Technologies, Carlsbad, California, USA), $2.2 \mu \mathrm{l}$ of $\mathrm{MgCl}_{2}(25 \mathrm{mM}), 0.4 \mu \mathrm{l}$ of deoxyribonucleotide triphosphate mix $(10 \mathrm{mM}), 0.25 \mu \mathrm{l}$ of each primer $(25 \mathrm{nM}), 0.6 \mu \mathrm{l}$ of 360 GC Enhancer (Life Technologies), $0.2 \mu \mathrm{l}$ of AmpliTaq

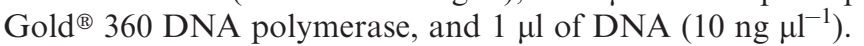
The small-subunit (SSU) rDNA was amplified using the primers 18S-F (5'-AAC CTG GTT GAT CCT GCC AGT$\left.3^{\prime}\right)$ and $18 \mathrm{~S}-\mathrm{R}$ (5'-TGA TCC TTC TGC AGG TTC ACC TAC G-3'; Katana et al. 2001), and the ITS rDNA region was amplified using the primers ITS 1 (5'-TCC GTA GGT GAA CCT GCG G-3') and ITS4 (5'-TCC TCC GCT TAT TGA TAT GC-3'; White et al. 1990). To amplify the $r b c \mathrm{~L}$ gene, we used the primers PRASF1 (5'-ATG GTT CCA CAA ACA GAA AC-3'; Sherwood et al. 2000), rbcL-203F (5'-GAA TCW TCW ACW GGW ACT TGG ACW AC-3'; Nelsen et al. 2011), and ellaR2 (5'-TCA CGA CCT TCA TTA CGA GCT TG-3'; Neustupa et al. 2013). Amplification of the SSU rDNA/ITS $/ r b c \mathrm{~L}$ markers started with an initial denaturation at $94^{\circ} \mathrm{C}$ for $4 / 4 / 5 \mathrm{~min}$, followed by $35 / 35 / 40$ cycles of denaturing at $94 / 94 / 95^{\circ} \mathrm{C}$ for $1 / 1 / 0.75 \mathrm{~min}$, annealing at $52 / 50 / 50^{\circ} \mathrm{C}$ for $1 / 1 / 1.5 \mathrm{~min}$, and elongation at $72^{\circ} \mathrm{C}$ for $2.5 / 1.5 / 2 \mathrm{~min}$, with a final extension at $72^{\circ} \mathrm{C}$ for 10 min, respectively. The PCR products were stained with bromophenol blue loading dye, quantified on a $1 \%$ agarose gel, stained with ethidium bromide, and cleaned with the JETQUICK PCR Purification Kit (Genomed, Löhne, Germany). The purified amplification products were sequenced using an Applied Biosystems (Foster City, California, USA) automated sequencer (ABI 3730xl) by Macrogen, Seoul, Korea. The sequences are available in the EMBL Nucleotide Sequence Database under accession numbers HF586459-HF586467 and HF674884-HF674885. Summing up, two new $r b c \mathrm{~L}$ sequences for the type strains of Chloroidium ellipsoideum (Gerneck) T. Darienko et al. (CAUP H1904) and C. saccharophilum (Krüger) T. Darienko et al. (H1912) and, in addition, three $18 \mathrm{~S}$ rDNA, $r b c \mathrm{~L}$ and ITS sequences of the strains H8501, H8502 and H8503 were published.

The newly determined SSU rDNA and $r b c \mathrm{~L}$ sequences were aligned with other sequences, obtained from the DDBJ/ EMBL/GenBank database, using MAFFT software (v. 6, QINS-i strategy; Katoh et al. 2005). Four newly determined ITS rDNA sequences were highly divergent from all other sequences stored in the database. Their alignment was produced manually by using MEGA5 (Tamura et al. 2011). To evaluate the effect of different outgroup taxa and alignment strategies on the phylogenetic reconstructions, four different SSU rDNA alignments were produced for the phylogenetic analyses. Initially, 82 sequences were selected to encompass all known lineages in Trebouxiophyceae (Friedl \& Rybalka 2011; Leliaert et al. 2012), and were manually aligned with two different outgoup taxa. The alignment followed the secondary structure model of Chlamydomonas reinhardtii Dangeard vSSU rDNA (Wuyts et al. 2000). First, the sequences were aligned with the chlorophycean taxa $C$. bilatus Ettl, Chloromonas rosae Ettl, and Pleurastrum insigne Chodat. As an alternative, the outgroup was composed of prasinophytes Nephroselmis olivacea Stein, N. pyriformis (N. Carter) Ettl, and Pseudoscourfieldia marina (Throndsen) Manton. Next, we eliminated ambiguously aligned regions in both SSU rDNA alignments by using Gblocks software (v. 
0.91b; Castresana 2000), and produced four different alignments: (1) original, chlorophycean outgroup; (2) reduced, chlorophycean outgroup; (3) original, prasinophycean outgroup; (4) reduced, prasinophycean outgroup. The resulting original alignments comprised 1755 positions and the reduced alignments 1702 positions. Finally, we constructed the concatenated SSU rDNA $+r b c \mathrm{~L}$ alignment of 44 taxa for which both SSU and $r b c \mathrm{~L}$ sequences were available. The final alignments are available at http://botany.natur.cuni.cz/algo/ align/Parachloroidium.zip.

The most appropriate substitution models, selected by using the Bayesian information criterion in MEGA 5, were the GTR $+\mathrm{G}+\mathrm{I}$ model for the entire $18 \mathrm{~S}$ rDNA data set and the first and third codon position of $r b c \mathrm{~L}$, and the $\mathrm{JC}+\mathrm{G}+\mathrm{I}$ model for the second codon position of $r b c \mathrm{~L}$. The plastid genome of Parachlorella kessleri (B. Fott \& M. Nováková) L. Krienitz, E.H. Hegewald, D. Hepperle, V.A.R. Huss, T. Rohr, \& M. Wolf, strain SAG 211-11g, GenBank accession no. FJ968741 (Turmel et al. 2009) was used to identify the precise position of individual codons in the $r b c \mathrm{~L}$ gene sequences of Chloroidium and Parachloroidium strains. The phylogenetic trees were inferred with Bayesian inference using MrBayes (v. 3.1; Ronquist \& Huelsenbeck 2003). Two parallel Markov chain Monte Carlo runs were carried out for four million generations each, with one cold and three heated chains. Trees and parameters were sampled every 100 generations. Convergence of the two cold chains was assessed by calculating the average standard deviation of split frequencies (SDSF). The SDSF value between simultaneous runs was 0.01611 . In addition, convergence of the two cold chains was checked and 'burn-in' was determined using the 'sump' command and in the program Tracer, ver. 1.4 (Rambaut \& Drummond 2007). Bootstrap analyses were performed by maximum likelihood (ML) and weighted maximum parsimony (wMP) criteria in GARLI (v. 0.951; Zwickl 2006) and PAUP* (v. 4.0b10; Swofford 2002), respectively. ML analyses consisted of rapid heuristic searches (100 pseudoreplicates) using automatic termination (genthreshfortopoterm command set to 100,000). The wMP bootstrapping (1000 replications) was performed using heuristic searches with 100 random sequence-addition replicates, tree bisection reconnection swapping, and random addition of sequences (maxtrees set to 10,000 for each replicate), with gap characters treated as a fifth character state. Character weights were assigned using the rescaled consistency index on a scale of 0 to 1000 . New weights were based on the mean of the fit values for each character over all of the trees in memory.

The secondary structures of ITS2 rDNA sequences were initially constructed using the mfold web server (v. 2.3; Zuker 2003) on a minimum free-energy basis, with the folding temperature set to $20^{\circ} \mathrm{C}$. The common secondary structure illustration was created using VARNA (Darty et al. 2009) and was used to identify the compensatory base changes.

\section{RESULTS}

\section{Parachloroidium Neustupa \& Škaloud gen. nov.}

DESCRIPTION: Vegetative cells solitary and uninucleate, with globular outlines and thin, smooth cell walls. Chloroplast parietal, without a pyrenoid surrounded by starch grains, but with a central cluster composed of numerous pyrenoglobuli. Asexual reproduction only by autopores. Sexual reproduction not observed. Secondary carotenoids not produced. The type species of this genus differs from other members of Trebouxiophyceae in the $18 \mathrm{~S}$ rDNA, ITS, and $r b c \mathrm{~L}$ sequences.

ETYMOLOGY: Generic name chosen to emphasize the apparent sister phylogenetic position to the genus Chloroidium [the Greek prefix $\pi \alpha \rho \alpha$ - (para-) means 'next to' or 'near'].

TYPE SPECIES: Parachloroidium laureanum Neustupa \& Škaloud $s p$. nov.

\section{Parachloroidium laureanum Neustupa \& Škaloud sp. nov. Figs 1-8, 17-20}

DESCRIPTION: Vegetative cells solitary, uninucleate. Mature cells spherical, (2.5-)3.0-7.5(-9.8) $\mu \mathrm{m}$ in diameter. Single parietal, cupshaped chloroplast, sometimes divided into several lobes. Pyrenoid absent, but chloroplasts typically include a central cluster of pyrenoglobuli and starch grains. Asexual reproduction via two to eight elliptical or egg-shaped autospores, $2.5-3.5 \times 3.5-5.5 \mu \mathrm{m}$ in diameter. Sexual reproduction not observed.

HOLOTYPE: Strain CAUP C-H8501 permanently cryopreserved in CAUP Culture Collection (http://botany.natur.cuni.cz/algo/caup. $\mathrm{html}$ ). Also available from CAUP as a perpetually transferred culture, strain H8501, from which the holotype was derived.

HABITAT: Subaerophytic on the bark of trees.

SPECIES LOCALITY: Ankaran, Slovenia $\left(45^{\circ} 35^{\prime} 11.93^{\prime \prime} \mathrm{N}\right.$, $\left.13^{\circ} 42^{\prime} 35.15^{\prime \prime} \mathrm{E}\right)$, on the bark of Laurus nobilis.

ETYMOLOGY: Specific epithet reflects the host species (Laurus nobilis) of the holotype.

\section{Parachloroidium lobatum Neustupa \& Škaloud sp. nov. Figs 9-16, 21-22}

DESCRIPTION: Vegetative cells solitary, uninucleate. Mature cells spherical, (3.5-)4.0-10.5(-13.5) $\mu \mathrm{m}$ in diameter. Single parietal, cupshaped chloroplast, often with two lobes. True pyrenoid absent, but chloroplasts typically include a thylakoid-free space with starch grains. Asexual reproduction via two to eight elliptical or spherical autospores, 3.0-6.5 $\mu \mathrm{m}$ in diameter. Sexual reproduction not observed. This species differs from the type species of the genus Parachlorodium in the $18 \mathrm{~S}$ rDNA, ITS, and $r b c \mathrm{~L}$ sequences.

HOLOTYPE: Strain CAUP C-H8502 permanently cryopreserved in CAUP Culture Collection (http://botany.natur.cuni.cz/algo/caup. html). Also available in CAUP as a perpetually transferred culture, strain H8502, from which the holotype was derived.

HABITAT: Subaerophytic on the bark of trees.

TYPE LOCALITY: Pacug, Slovenia $\left(45^{\circ} 31^{\prime} 33.55^{\prime \prime} \mathrm{N}, 13^{\circ} 35^{\prime} 40.95^{\prime \prime} \mathrm{E}\right)$, on the bark of Fraxinus ornus.

ETYMOLOGY: Specific epithet reflects the characteristic lobate shape of the chloroplasts.

All four strains investigated in this study shared general morphological characteristics common to the Chlorella-like green microalgae. They were unicellular, with spherical or elliptical cells, and with single parietal plastids (Figs 1-4, 913). They reproduced by two to eight asexual autospores 


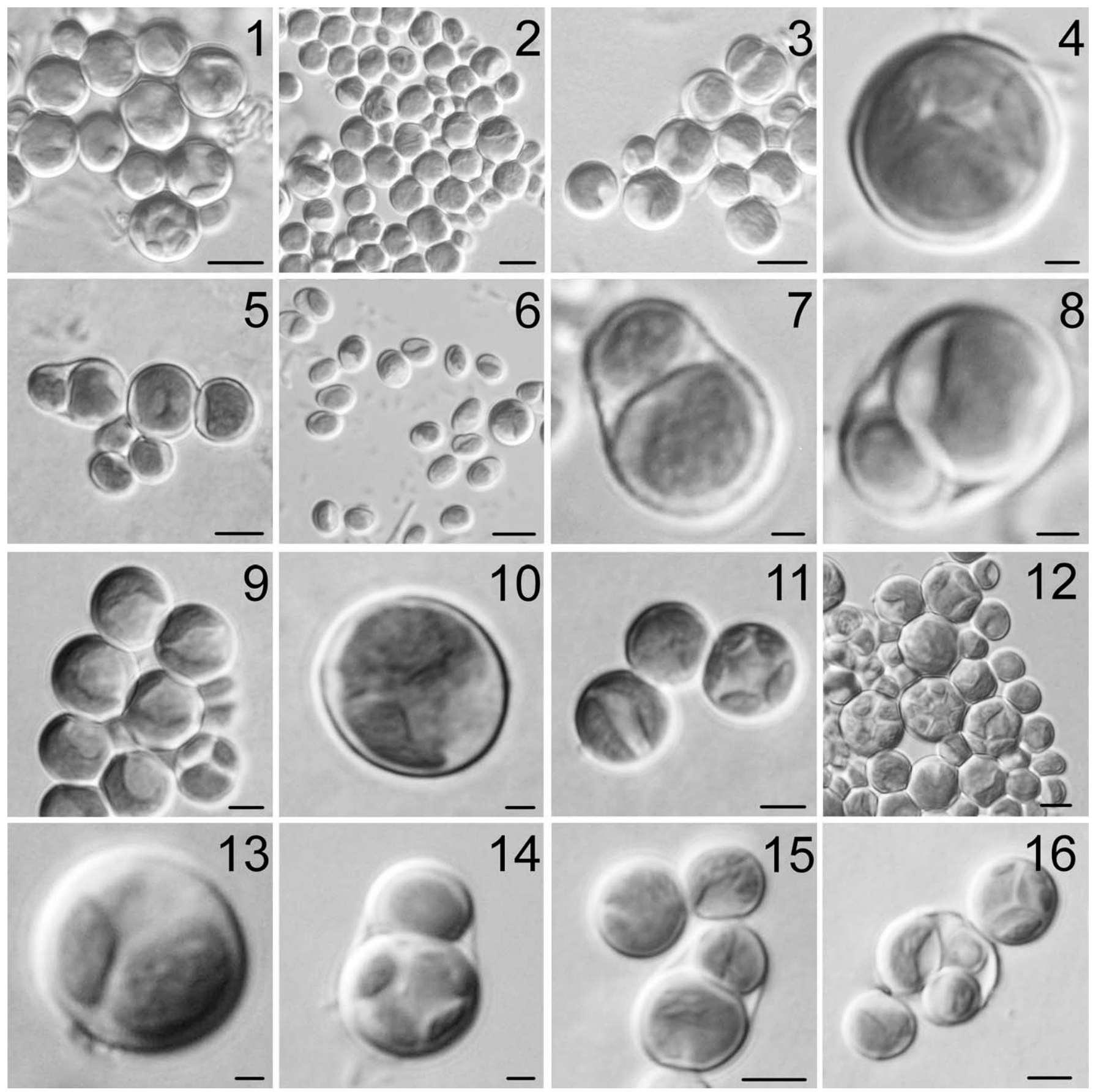

Figs 1-16. Morphology of Parachloroidium laureanum sp. nov. and P. lobatum sp. nov.

Figs 1-3. Vegetative cells and autosporangia of $P$. laureanum, strain CAUP H8501. Scale bar $=5 \mu \mathrm{m}$.

Fig. 4. Detail of mature vegetative cell of $P$. laureanum, strain CAUP H8501. Scale bar $=1 \mu \mathrm{m}$.

Fig. 5. Vegetative cells and the two-celled autosporangium of $P$. laureanum, strain CAUP H8501. Scale bar $=5 \mu \mathrm{m}$.

Fig. 6. Young vegetative cells of $P$. laureanum, strain CAUP H8501. Scale bar $=5 \mu \mathrm{m}$.

Figs 7, 8. Two-celled autosporangia of $P$. laureanum, strain CAUP H8501. Scale bar $=1 \mu \mathrm{m}$.

Figs 9-11. Vegetative cells and autosporangia of $P$. lobatum, strain CAUP H8502. Scale bar $=5 \mu \mathrm{m}($ Figs 9,11$)$; scale bar $=1 \mu \mathrm{m}($ Fig. 10$)$.

Fig. 12. Vegetative cells and autosporangia of P. lobatum, strain CAUP H8502. Scale bar $=5 \mu \mathrm{m}$.

Figs 13, 14. Detail of mature vegetative cell with two distinct chloroplast lobes and the two-celled autosporangium of $P$. lobatum, strain CAUP H8502. Scale bar $=1 \mu \mathrm{m}$.

Figs 15, 16. Vegetative cells and autosporangia of P. lobatum, strain CAUP H8503. Scale bar $=5 \mu \mathrm{m}$. 
(Figs 5-8, 14-16). In most cells, a single relatively large autospore and one, three, or seven considerably smaller autospores were produced within a single sporangium (Figs 7-8, 12, 14-15). The autospores of Parachloroidium laureanum, strain CAUP H8501, were typically elliptical or irregularly egg shaped (Fig. 6). Conversely, the autospores of P. lobatum, strain CAUP H8502, were more or less spherical in shape (Fig. 12). The mature cells and autosporangia of all the strains assigned here into the genus Parachloroidium were regularly spherical. The plastids of $P$. laureanum were often slightly detached from the cytoplasmic membrane at its parietal side. Therefore, in a side view, the plastid often appeared as a flat plate separating two cytoplasmic regions of the cell (Figs 8, 17, 18). Conversely, the plastids of $P$. lobatum were more or less cup shaped, i.e. they typically had conspicuous lobes and a central incision (Figs 10-13). True pyrenoids were absent in both species, but plastids of $P$. laureanum cells included numerous pyrenoglobuli arranged in a central thylakoid-free region that sometimes also included oval to spherical starch grains (Figs 17-20). The chloroplasts of P. lobatum also typically included thylakoid-free regions with irregularly arranged strach grains, but pyrenoglobuli were absent (Figs 21, 22). The cell walls of Parachloroidium strains were unsculptured. Autosporangial cell wall remnants of $P$. laureanum rapidly dissolved in the medium. Conversely, cell wall remnants of $P$. lobatum were significantly more resistant and they were frequently observed surrounding the former autospores (Fig. 21).

\section{Molecular phylogeny}

ITS rDNA, SSU rDNA, and $r b c \mathrm{~L}$ DNA sequences were obtained from all four Parachloroidium strains. In addition, the plastid-encoded $r b c \mathrm{~L}$ gene sequences were determined for the authentic strains of two Chloroidium species, C. ellipsoideum (Gerneck) Darienko et al. (CAUP H1904) and $C$. saccharophilum (W. Krüger) Darienko et al. (CAUP H1912). The phylogenetic position of Parachloroidium strains within Trebouxiophyceae was inferred by analysing the DNA sequences of the slowly evolving $18 \mathrm{~S}$ rDNA and $r b c \mathrm{~L}$ genes. To test the robustness of the phylogeny, four different $18 \mathrm{~S}$ rDNA gene analyses were conducted using variations in outgroup taxa and alignment strategies. The results of these four analyses were in agreement: the major clades were resolved with very similar statistical support (Table 1). All Parachloroidium strains formed a firmly supported monophyletic lineage (1.00 Bayesian posterior probability/100 ML bootstrap support/100 wMP bootstrap support) within the Watanabea clade of Trebouxiophyceae (Fig. 23). Three $P$. lobatum strains (CAUP H8502, CAUP H8503, I6e) were closely related $(0.98 / 84 / 89)$. The $18 \mathrm{~S}$ rDNA sequences of the strains CAUP H8502 and I6e were identical, but strain CAUP H8503 differed by five substitution changes and one deletion of three nucleotides from two previous strains of this species. The entire genus Parachloroidium was consistently placed in a highly supported sister position to the genus Chloroidium (1.00/93/90). The Watanabea clade also comprised the genera Heterochlorella, Heveochlorella, Kalinella, Phyllosiphon, Viridiella, and Watanabea. Sequences of three taxonomically unidentified trebouxiophycean strains ("Chlorella" sp. MBIC
10057, uncultured "Chlorella" L-1016 and "Chlorella luteoviridis" MES A5-4) were also firmly nested within this clade.

The topology of the phylogenetic tree derived from the analysis of the concatenated $18 \mathrm{~S}$ rDNA $+r b c \mathrm{~L}$ sequences (Fig. 24) illustrated that the monophyletic genus Parachloroidium $(1.00 / 100 / 100)$ was recovered in a firmly supported sister position with the genus Chloroidium (1.00/100/100). The Parachloroidium strains and two authentic strains of the Chloroidium species shared a single amino acid insertion (Lys), coded as 'AAG' in Parachloroidium and 'AAA' in Chloroidium, at position 286 in the $r b c \mathrm{~L}$ gene sequence. The genera Chloroidium and Parachloroidium formed a part of the Watanabea clade, together with the sequences of the authentic strains of Heterochlorella luteoviridis (Chodat) Neustupa et al., Kalinella bambusicola Neustupa et al., and K. apyrenoidosa Neustupa et al. (1.00/100/100). Three strains of P. lobatum (CAUP H8502, CAUP H8503, I6e) had identical $r b c \mathrm{~L}$ sequences.

ITS rDNA sequences were obtained for all four Parachloroidium strains. Intragenomic variation in four nucleotide sites was found in the ITS1 region of $P$. laureanum (CAUP H8501). The basic local alignment search tool (BLAST) searches of $5.8 \mathrm{~S}$ rDNA sequences showed that the best matches were to GenBank sequence no. FJ792803 [assigned as Dictyochloropsis reticulata (Tschermak-Woess) TschermakWoess] and to various Chloroidium species. However, the BLAST searches of ITS1 and ITS2 regions did not suggest any similar GenBank sequences, with the exception of the $P$. laureanum sequence, receiving 88\% identity with the FJ792803 sequence. No Chloroidium sequences were returned by the BLAST searches used to evaluate the homologies of the Parachloroidium ITS rDNA sequences. The ITS regions of $P$. lobatum strains CAUP H8502 and I6e were identical to one another; they differed from strain CAUP H8503 by four substitution changes in ITS1 and one deletion in ITS2. The single deletion was located in the terminal loop of helix II (Fig. 25). Consequently, no compensatory base changes were detected among the strains of P. lobatum. Conversely, the ITS rDNA sequence of $P$. laureanum CAUP H8501 was highly diverse. The overall divergence between the ITS2 rDNA sequences of $P$. laureanum and $P$. lobatum was approximately $27 \%$. Most of the differences were in helices III and IV and a total of seven compensatory base changes were identified (Fig. 25).

\section{DISCUSSION}

Several recent studies based on molecular data have revealed rather unexpected phylogenetic diversity within the Chlorella-like green algae (Krienitz et al. 2004; Darienko et al. 2010; Luo et al. 2010; Bock et al. 2011). The taxa are now distributed over multiple genus-level lineages in the green algal classes Trebouxiophyceae and Chlorophyceae (Leliaert et al. 2012). Numerous Chlorella-like taxa have been isolated from various freshwater ecosystems (Krienitz \& Bock 2012); they have also, more rarely, been observed in marine habitats (Aslam et al. 2007). These microalgae are probably most abundant and diversified in subaerial biofilms and in soil, where they are constituents of microbial assemblages (Ettl \& 


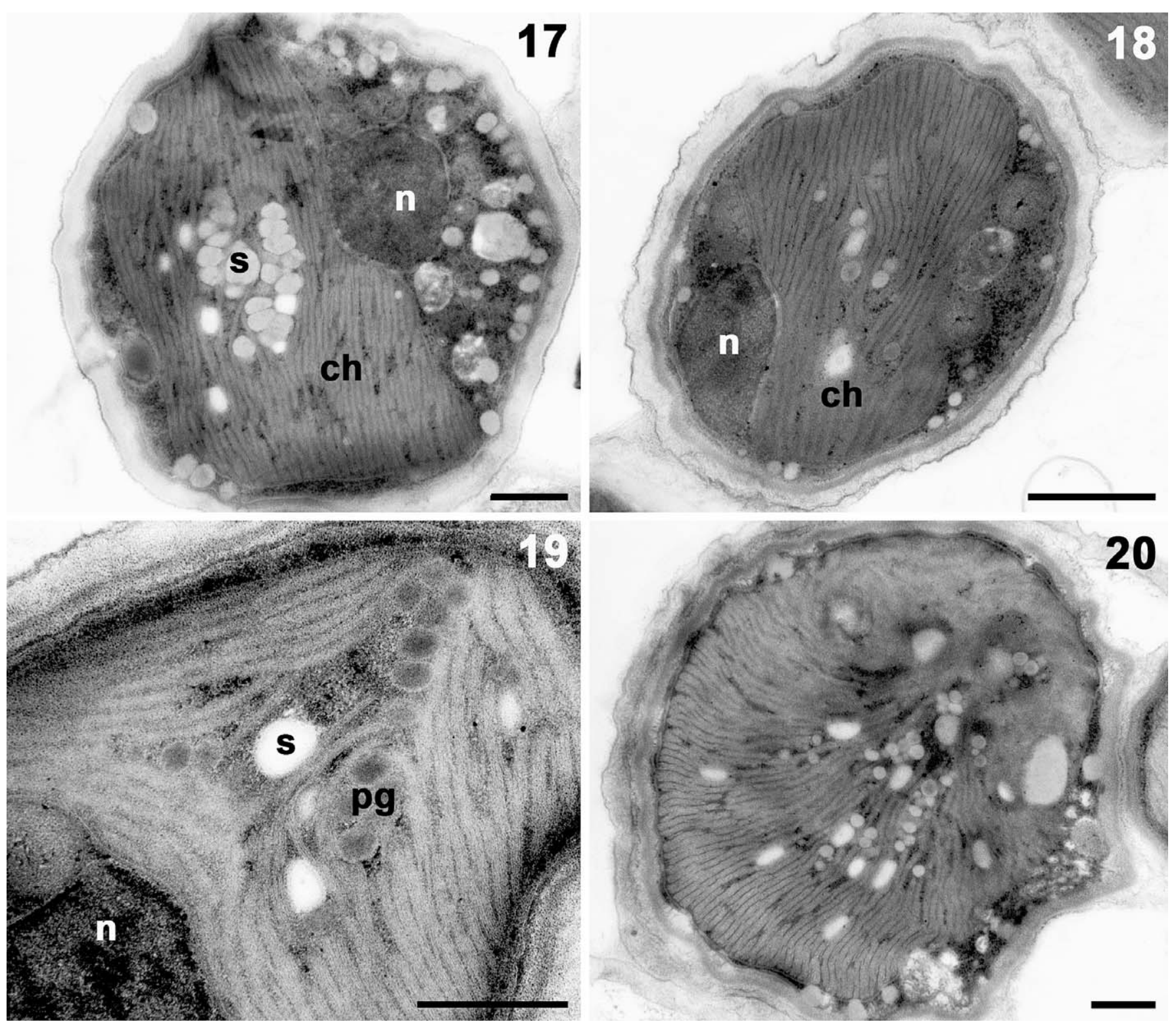

Figs 17-20. Ultrastucture of Parachloroidium laureanum sp. nov., strain CAUP H8501; $\mathrm{ch}=$ chloroplast, $\mathrm{n}=\mathrm{nucleus,} \mathrm{pg}=\mathrm{pyrenoglobuli}, \mathrm{s}=$ starch grains. Scale bars $=0.5 \mu \mathrm{m}$.

Figs 17, 18. Vegetative cells of $P$. laureanum, strain CAUP H8501, with single nuclei and plastids containing numerous pyrenoglobuli and starch grains.

Fig. 19. Details of pyrenoglobuli and starch grains located in the chloroplast matrix of $P$. laureanum, strain CAUP H8501.

Fig. 20. Vegetative cells of $P$. laureanum, strain CAUP H8501, with numerous starch grains and pyrenoglobuli loated in the chloroplast matrix.

Gärtner 1995). In these habitats, microalgal populations are subject to aperiodic drying and rewetting cycles and, therefore, they must be able to cope with significant desiccation stress (Lüttge \& Büdel 2010). The conditions they experience generally lead to selection for spherical cells with relatively low surface-to-volume ratios. Consequently, Chlorella-like morphotypes evolved several times independently in multiple trebouxiophycean and chlorophycean lineages in terrestrial habitats (Friedl \& Rybalka 2011). Correct phylogenetic classification of these microorganisms is a prerequisite for evaluating the diversity and structure of these little-known microbial phototrophic communities.
The unicellular members of the Watanabea clade, which mostly occur in terrestrial habitats, cannot usually be identified by traditional light and electron microscopy. Morphological criteria, such as cell size, shape of the individual ontogenetic stages (autospores, vegetative cells, autosporangia), or plastid structure, typically cannot be used to discriminate between individual members of this trebouxiophycean lineage. However, morphological characters may be very useful for a posteriori phenotypic definition of genuslevel lineages that were previously identified by means of molecular data. The Parachloroidium lineage may be morphologically distinguished from its sister genus Chloroi- 

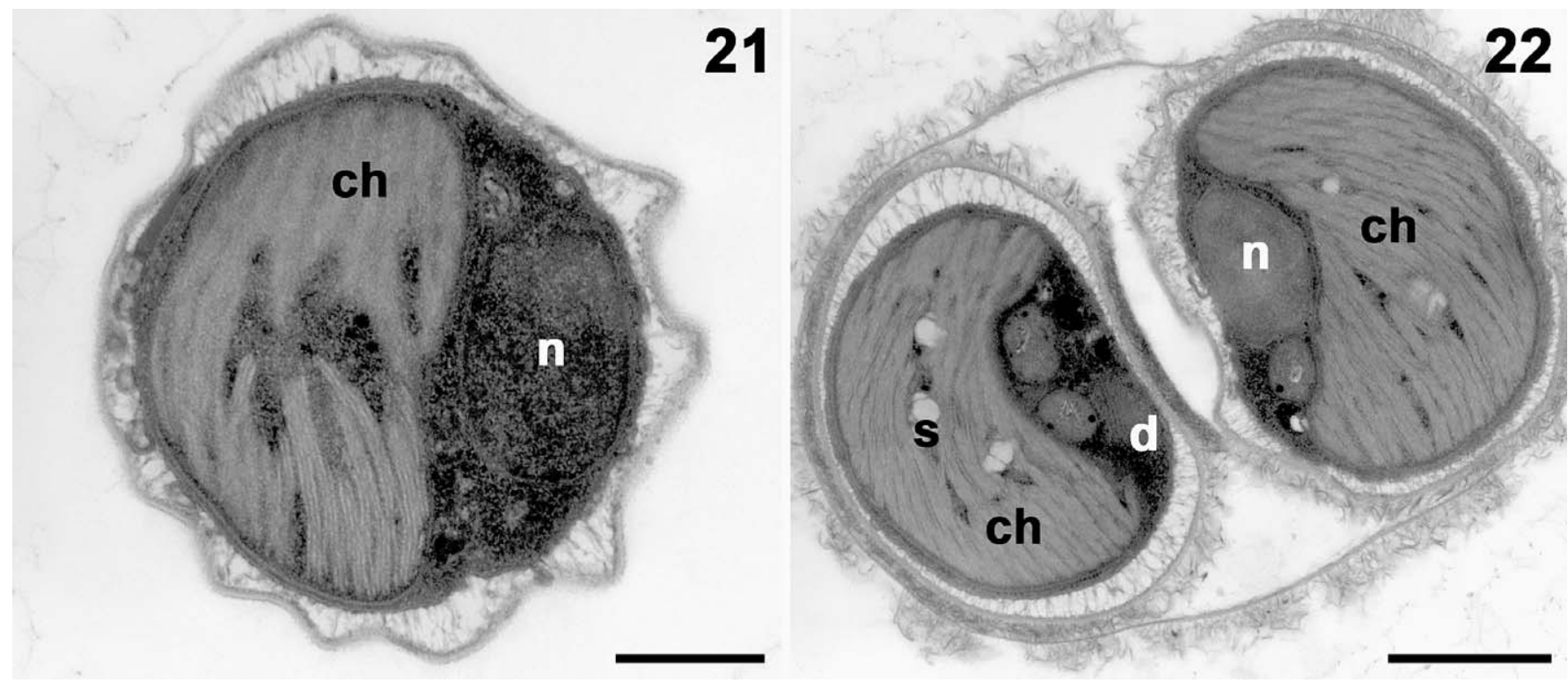

Figs 21, 22. Vegetative cells and autospores of Parachloroidium lobatum sp. nov., strain CAUP H8502; $\mathrm{ch}=$ chloroplast, $\mathrm{d}=$ dictyosome, $\mathrm{n}=$ nucleus, $\mathrm{s}=$ starch grains. Scale bar $=0.5 \mu \mathrm{m}$.

Fig. 21. A vegetative cell of $P$. lobatum, strain CAUP H8502, showing the irregular thylakoid-free region located within the chloroplast.

Fig. 22. Two autospores of $P$. lobatum, strain CAUP H8502, with plastids containing scattered starch grains.

dium mainly by its regular spherical cell shapes and by the peculiar structure of its plastids, which typically contain irregular thylakoid-free regions with clusters of pyrenoglobuli and starch grains. In contrast, the cells of Chloroidium species typically possess oval pyrenoids, composed of an amorphous matrix that may sometimes be penetrated by thylakoid bands and surrounded by a starch envelope (Ikeda \& Takeda 1995). Similar pyrenoids have been observed in several other taxa belonging to the Watanabea clade, such as Heterochlorella luteoviridis, Heveochlorella hainangensis, and K. bambusicola (Zhang et al. 2008; Neustupa et al. 2009). Conversely, no pyrenoids were observed in other members of the clade, such as Viridiella fridericiana P.Albertano, A.Pollio \& R.Taddei, Phyllosiphon arisari Kühn, and Kalinella apyrenoidosa (Huss et al. 2002; Aboal \& Werner 2011; Neustupa et al. 2013). Plastids of $W$. reniformis also lack pyrenoids, but they do include thylakoid-free regions with pyrenoglobuli, i.e. structures vaguely similar to those observed in Parachloroidium strains (Hanagata et al. 1998). However, the relatively distant phylogenetic position of the genera Watanabea and Parachloroidium indicates that this ultrastructural character cannot be used to identify evolutionary relationships within the clade.

Two species were identified within the newly described genus Parachloroidium. They were primarily distinguished by differences in their molecular data, but slight morphological differences were also observed. There were 17 different nucleotide positions in the SSU rDNA sequence between the type strains of the two species; these differences were even more pronounced in the $r b c \mathrm{~L}$ gene. In addition, the ITS2 sequences of the two strains were highly diverse, which supported the independent species status of both taxa.

Table 1. Comparison of node resolutions [Bayesian inference (BI)/maximum likelihood (ML)/weighted maximum parsimony (wMP)] for the four different small-subunit (SSU) ribosomal (r)DNA phylogenetic analyses.

\begin{tabular}{|c|c|c|c|c|}
\hline & $\begin{array}{c}\text { Original } \\
\text { alignment, } \\
\text { outgroup: } \\
\text { Chlorophyceae }\end{array}$ & $\begin{array}{c}\text { Reduced } \\
\text { alignment, } \\
\text { outgroup: } \\
\text { Chlorophyceae }\end{array}$ & $\begin{array}{c}\text { Original } \\
\text { alignment, } \\
\text { outgroup: } \\
\text { prasinophytes }\end{array}$ & $\begin{array}{c}\text { Reduced } \\
\text { alignment, } \\
\text { outgroup: } \\
\text { prasinophytes }\end{array}$ \\
\hline Botryococcus clade & $1.00 / 70 / 79$ & $1.00 / 67 / 78$ & $1.00 / 63 / 81$ & $1.00 / 70 / 81$ \\
\hline Chlorellales & $0.92 /-/ 52$ & $0.98 /-/ 52$ & $0.99 /-/ 52$ & $0.99 /-/ 51$ \\
\hline Chloroidium-Kalinella clade & $1.00 / 86 / 87$ & $1.00 / 71 / 86$ & $1.00 / 70 / 90$ & $0.99 / 74 / 91$ \\
\hline Dictyochloropsis & $1.00 / 100 / 100$ & $1.00 / 100 / 100$ & $1.00 / 100 / 100$ & $1.00 / 99 / 100$ \\
\hline Leptochlorella & $1.00 / 100 / 100$ & $1.00 / 100 / 100$ & $1.00 / 100 / 100$ & $1.00 / 100 / 100$ \\
\hline Lobosphaera clade & $1.00 / 100 / 100$ & $1.00 / 100 / 100$ & $1.00 / 100 / 100$ & $1.00 / 100 / 100$ \\
\hline Microthamniales & $1.00 / 100 / 100$ & $1.00 / 100 / 100$ & $1.00 / 100 / 100$ & $1.00 / 100 / 100$ \\
\hline Parietochloris & $1.00 / 86 / 99$ & $1.00 / 86 / 99$ & $1.00 / 91 / 99$ & $1.00 / 95 / 100$ \\
\hline Prasiola clade & $1.00 / 100 / 100$ & $1.00 / 98 / 100$ & $1.00 / 96 / 100$ & $1.00 / 95 / 100$ \\
\hline Trebouxiales & $1.00 / 96 / 96$ & $1.00 / 94 / 95$ & $1.00 / 93 / 93$ & $1.00 / 95 / 94$ \\
\hline Watanabea clade & $1.00 / 77 /-$ & $1.00 / 63 /-$ & $1.00 / 68 /-$ & $1.00 / 66 /-$ \\
\hline Xylochloris & $1.00 / 89 / 99$ & $1.00 / 88 / 99$ & $1.00 / 90 / 100$ & $1.00 / 94 / 100$ \\
\hline outgroup & $1.00 / 100 / 100$ & $1.00 / 100 / 100$ & $1.00 / 100 / 100$ & $1.00 / 100 / 100$ \\
\hline
\end{tabular}




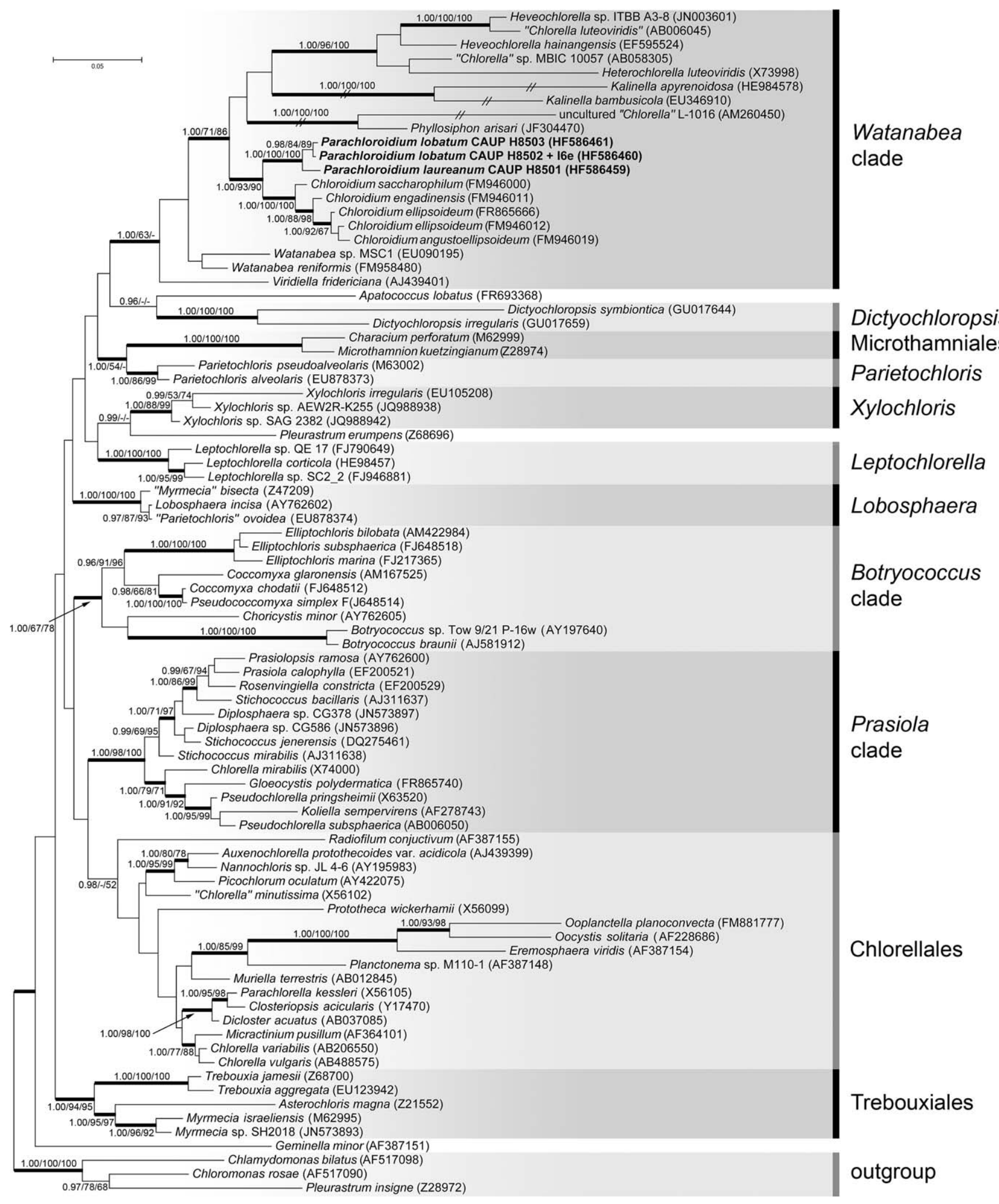

Fig. 23. Phylogenetic position of the genus Parachloroidium within the class Trebouxiophyceae (Chlorophyta), based on 18S rDNA sequences. The analysis was based on reduced alignment with an outgroup formed by the three chlorophycean species. The tree was inferred using MrBayes with the GTR $+\mathrm{G}+\mathrm{I}$ evolutionary model. Numbers at the branches correspond to MrBayes posterior probabilities/ maximum likelihood (ML) bootstrap values/weighted maximum parsimony (wMP) bootstrap values. Values below 0.95 Bayesian posterior probability (BPP) or 50\% ML and wMP bootstrap support are not shown. Thick branches represent nodes receiving the highest BPP support (1.00). The scale bar shows the estimated number of substitutions per site. 


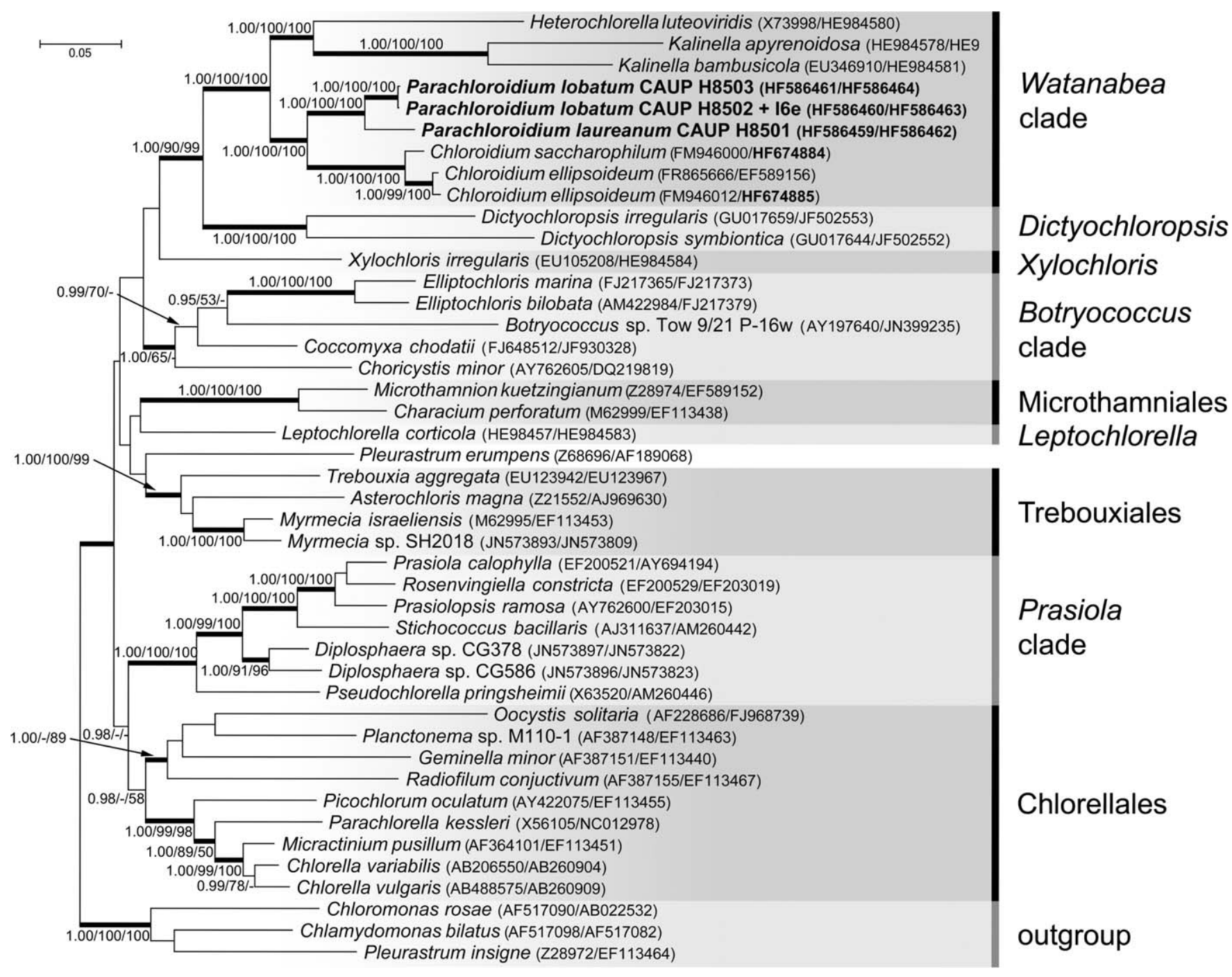

Fig. 24. Phylogenetic position of Parachloroidium within the class Trebouxiophyceae (Chlorophyta), based on the combined $18 \mathrm{~S}$ rDNA + $r b c \mathrm{~L}$ data set. The tree was inferred using MrBayes with the GTR $+\mathrm{G}+\mathrm{I}$ evolutionary model applied to the entire 18S rDNA data set and the first and third codon positions of $r b c \mathrm{~L}$, and the $\mathrm{JC}+\mathrm{G}+\mathrm{I}$ model applied to the second codon position of $r b c \mathrm{~L}$. Numbers at the branches correspond to MrBayes posterior probabilities/maximum likelihood (ML) bootstrap values/weighted maximum parsimony (wMP) bootstrap values. Values below 0.95 Bayesian posterior probability (BPP) or $50 \%$ ML and wMP bootstrap support are not shown. Thick branches represent nodes receiving the highest BPP support (1.00). The GenBank accession numbers for individual taxa refer to $18 \mathrm{~S}$ rDNA/rbcL sequences. The scale bar shows the estimated number of substitutions per site.

Variation in sequence data was also observed between strains CAUP H8502 and H8503, which were assigned to $P$. lobatum. Five substitution changes and one deletion of three nucleotides in the 18S rDNA sequences were accompanied by a single deletion in the terminal loop of helix III of the ITS2 region. We did not interpret the observed variability in molecular data as sufficient for the formal taxonomic differentiation of these strains. This conclusion was also supported by the homogeneity in their morphological characteristics.

Friedl \& Rybalka (2011) published an overview of trebouxiophycean lineages, and included the Watanabea clade as one of five well-recognised higher-level clades of this algal class. Following several recent taxonomic additions (Aboal \& Werner 2011; Ma et al. 2013; Neustupa et al. 2013), the Watanabea clade may now be considered one of the trebouxiophycean lineages that mostly include taxa occurring in terrestrial microhabitats. The members of at least two genera of the clade-Chloroidium and Heterochlorella - were found in multiple molecular diversity studies, and several strains, identified by molecular methods, are available in culture collections (Hallmann et al. 2011; Thüs et al. 2011; Lee \& Hur 2012). Conversely, the genus Parachloroidium has so far not been reported from comparable environmental sequence data and we may speculate that it is possibly a relatively rare taxon, or one with an ecologically restricted distribution. Interestingly, the ITS sequence no. FJ792803 was the most similar to Parachloroidium sequences. This sequence was isolated from the lichen Lobaria pulmonaria (Linnaeus) Hoffmann in Spain (Gasulla et al. 2010), and may represent an additional species of the Chloroidium/Parachloroidium lineage. However, detailed 


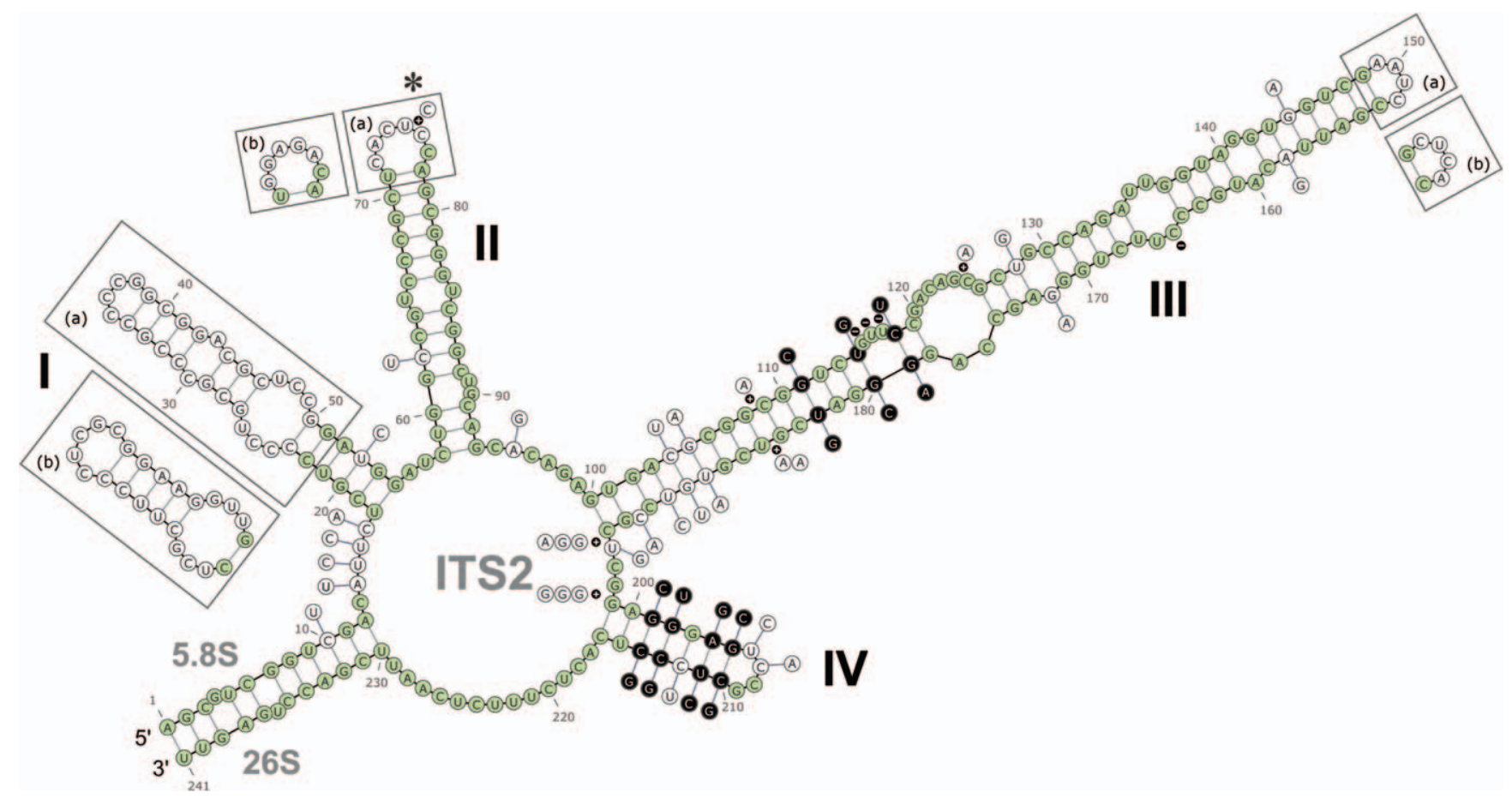

Fig. 25. Comparison of the ITS 2 sequences and predicted secondary structures of Parachloroidium lobatum and P. laureanum. Base numbering is indicated every 10 bases, and the four helices are numbered with Roman numerals. The illustrated structure corresponds to $P$. lobatum CAUP H8502; the single nucleotide insertion differentiating strain CAUP H8503 of $P$. lobatum from the type strain of this species is marked by an asterisk. Positions conserved in P. laureanum are portrayed in green; the bases substituted in P. laureanum are shown by the structure and connected to the respective positions by short lines; insertions and deletions are indicated with plus and minus symbols, respectively. Major differences between the ends of the helices between P. lobatum (a) and P. laureanum (b) are shown in boxes.

distribution patterns of Parachloroidium and related genera in the Watanabea clade can only be established once more data on the molecular diversity of phototrophic corticolous biofilms and other subaerial microalgal assemblages have been collected.

\section{ACKNOWLEDGEMENTS}

We thank Gašper Polajnar from the National Institute of Biology, Piran, Slovenia for providing the base for field sampling. This work was supported by a grant from the Czech Science Foundation (no. P506/12/0955). We thank the anonymous reviewers for their recommendations that led us to the improvements of the manuscript. We also thank BioEdit Ltd (UK) for English language editing and style corrections.

\section{REFERENCES}

Aboal M. \& Werner O. 2011. Morphology, fine structure, life cycle and phylogenetic analysis of Phyllosiphon arisari, a siphonous parasitic green alga. European Journal of Phycology 46: 181-192.

Andersen R.A., Berges J.A., Harrison P.J. \& Watanabe M.M. 2005. Recipes for freshwater and seawater media. In: Algal culturing techniques (Ed. by R.A. Andersen), pp. 429-538. Elsevier Academic Press, San Diego.

Aslam Z., Shin W.G., Kim M.K., Im W.T. \& Lee S.T. 2007. Marinichlorella kaistiae gen. et sp. nov. (Trebouxiophyceae,
Chlorophyta) based on polyphasic taxonomy. Journal of Phycology 43: 576-584.

Bock C., Krienitz L. \& Pröschold T. 2011. Taxonomic reassessment of the genus Chlorella (Trebouxiophyceae) using molecular signatures (barcodes), including description of seven new species. Fottea 11: 293-312.

Castresana J. 2000. Selection of conserved blocks from multiple alignments for their use in phylogenetic analysis. Molecular Biology and Evolution 17: 540-552.

Coleman A.W. 2009. Is there a molecular key to the level of "biological species" in eukaryotes? A DNA guide. Molecular Phylogenetics and Evolution 50: 197-203.

Darienko T., Gustavs L., Mudimu O., Menendez C.R., Schumann R., Karsten U., Friedl T. \& Pröschold T. 2010. Chloroidium, a common terrestrial coccoid green alga previously assigned to Chlorella (Trebouxiophyceae, Chlorophyta). European Journal of Phycology 45: 79-95.

Darty K., Denise A. \& Ponty Y. 2009. VARNA: interactive drawing and editing of the RNA secondary structure. Bioinformatics 25: 1974-1975.

Ettl H. \& GÄrtner G. 1995. Syllabus der Boden-, Luft- und Flechtenalgen. G. Fischer, Stuttgart. 721 pp.

FriedL T. \& RybalKa N. 2011. Systematics of the green algae: a brief introduction to the current status. In: Progress in botany 73 (Ed. by U. Lüttge, W. Beyschlag, B. Büdel \& D. Francis), pp. 259-280. Springer, Heidelberg.

Gasulla F., Guéra A. \& Barreno E. 2010. A simple and rapid method for isolating lichen photobionts. Symbiosis 51: 175-179.

Hallmann C., Rüdrich J., Enseleit M., Friedl T. \& Hoppert M. 2011. Microbial diversity on a marble monument: a case study. Enviromental Earth Sciences 63: 1701-1711.

Hallmann C., Stannek L., Fritzlar D., Hause-Reitner D., FriedL T. \& Hoppert M. 2013. Molecular diversity of phototrophic biofilms on building stone. FEMS Microbiology Ecology: DOI: 10.1111/1574-6941.12065 
Hanagata N., Karube I., Chihara M. \& Silva P.C. 1998. Reconsideration of the taxonomy of ellipsoidal species of Chlorella (Trebouxiophyceae, Chlorophyta), with establishment of Watanabea gen. nov. Phycological Research 46: 221-229.

Huss V.A.R., Ciniglia C., Cennamo P., Cozzolino S., Pinto G. \& Pollio A. 2002. Phylogenetic relationships and taxonomic position of Chlorella-like isolates from low $\mathrm{pH}$ environments (pH < 3.0). BMC Evolutionary Biology 2: 13.

IKeDA T. \& TAKeda H. 1995. Species-specific differences of pyrenoids in Chlorella (Chlorophyta). Journal of Phycology 31: 813-818.

Karsten U., Friedl T., Schumann R., Hoyer K. \& Lembcke S. 2005. Mycosporine-like amino acids and phylogenies in green algae: Prasiola and its relatives from the Trebouxiophyceae (Chlorophyta). Journal of Phycology 41: 557-566.

Katana A., Kwiatowski J., Spalik K., Zakrys B., Szalacha E. \& Szymanska H. 2001. Phylogenetic position of Koliella (Chlorophyta) as inferred from nuclear and chloroplast small subunit rDNA. Journal of Phycology 37: 443-451.

Katoh K., Kuma K., Toh H. \& Miyata T. 2005. MAFFT version 5: improvement in accuracy of multiple sequence alignment. Nucleic Acids Research 33: 511-518.

Krienitz L. \& Bock C. 2012. Present state of the systematics of planktonic coccoid green algae of inland waters. Hydrobiologia 698: 295-326.

Krienitz L., Hegewald E.H., Hepperle D., Huss V.A.R., Rohr T. \& Wolf M. 2004. Phylogenetic relationship of Chlorella and Parachlorella gen. nov. (Chlorophyta, Trebouxiophyceae). Phycologia 43: 529-542.

Lee H.J. \& Hur S.B. 2012. Comparison between phylogenetic relationships based on 18S rDNA sequences and growth by salinity of Chlorella-like species (Chlorophyta). Fisheries and Aquatic Sciences 15: 125-135.

Leliaert F., Smith D.R., Moreau H., Herron M.D., Verbruggen H., Delwiche C.D. \& De Clerck O. 2012. Phylogeny and molecular evolution of the green algae. Critical Reviews in Plant Sciences 31: 1-46.

Luo W., Pröschold T., Bock C. \& Krienitz L. 2010. Generic concept in Chlorella-related coccoid green algae (Chlorophyta, Trebouxiophyceae). Plant Biology 12: 545-553.

Lüttge U. \& Büdel B. 2010. Resurrection kinetics of photosynthesis in desiccation-tolerant terrestrial green algae (Chlorophyta) on tree bark. Plant Biology 12: 437-444.

Ma S., Huss V.A.R., Tan D., Sun X., Chen J., Xie Y. \& Zhang J. 2013. A novel species in the genus Heveochlorella (Trebouxiophyceae, Chlorophyta) witnesses the evolution from an epiphytic into an endophytic lifestyle in tree-dwelling green algae. European Journal of Phycology 48: 200-209.

Müller T., Philippi N., Dandekar T., Schultz J. \& Wolf M. 2007. Distinguishing species. RNA 13: 1469-1472.

Nelsen M.P., Rivas Plata E., Andrew C.J., Lücking R. \& Lumbsch H.T. 2011. Phylogenetic diversity of trentepohlialean algae associated with lichen-forming fungi. Journal of Phycology 47: $282-290$

Neustupa J., Němcová Y., Eliáš M. \& Škaloud P. 2009. Kalinella bambusicola gen. et sp. nov. (Trebouxiophyceae, Chlorophyta), a novel coccoid Chlorella-like subaerial alga from Southeast Asia. Phycological Research 57: 159-169.

Neustupa J., Němcová Y., Veselá J., Steinová J. \& Škaloud P. 2013. Leptochlorella corticola gen. et sp. nov. and Kalinella apyrenoidosa sp. nov.: two novel Chlorella-like green microalgae (Trebouxiophyceae, Chlorophyta) from subaerial habitats. International Journal of Systematic and Evolutionary Microbiology 63: 377-387.
Nyati S., Beck A. \& Honegger R. 2007. Fine structure and phylogeny of green algal photobionts in the microfilamentous genus Psoroglaena (Verrucariaceae, lichen-forming Ascomycetes). Plant Biology 9: 390-399.

Rambaut A. \& Drummond A.J. 2007. Tracer v1.4. World-wide electronic publication, http://beast.bio.ed.ac.uk/Tracer (31 May 2013).

Ronquist F. \& Huelsenbeck J.P. 2003. MrBayes 3: Bayesian phylogenetic inference under mixed models. Bioinformatics 19: $1572-1574$

Sherwood A.R., Garbary D.J. \& Sheath R.G. 2000. Assessing the phylogenetic position of the Prasiolales (Chlorophyta) using $r b c \mathrm{~L}$ and 18S rRNA gene sequence data. Phycologia 39: 139-146.

ŠKaloud P., ŠŤastný J., Nemjová K., Mazalová P., PoulíčKová A. \& Neustupa J. 2012. Molecular phylogeny of baculiform desmid taxa (Zygnematophyceae). Plant Systematics and Evolution 298: $1281-1292$

SwOFFORD D.L. 2002. PAUP*: phylogenetic analysis using parsimony (and other methods). Sinauer Associates, Sunderland, Massachusetts.

Tamura K., Peterson D., Peterson N., Stecher G., Nei M. \& Kumar S. 2011. MEGA5: molecular evolutionary genetics analysis using maximum likelihood, evolutionary distance, and maximum parsimony methods. Molecular Biology and Evolution 28: 2731-2739.

Thüs H., Muggia L., Pérez-Ortega S., Favero-Longo S.E., Joneson S., O’Brien H., Nelsen M.P., Duque-Thüs R., Grube M., Friedl T., Brodie J., Andrew C.J., Lücking R., Lutzoni F. \& GUEIDAN C. 2011. Revisiting photobiont diversity in the lichen family Verrucariaceae (Ascomycota). European Journal of Phycology 46: 399-415.

Turmel M., Otis C. \& Lemieux C. 2009. The chloroplast genomes of the green algae Pedinomonas minor, Parachlorella kessleri, and Oocystis solitaria reveal a shared ancestry between the Pedinomonadales and Chlorellales. Molecular Biology and Evolution 26: 2317-2331.

White T.J., Bruns T., Lee S. \& Taylor J. 1990. Amplification and direct sequencing of fungal ribosomal RNA genes for phylogenetics. In: PCR protocols: a guide to methods and applications (Ed. by M.A. Innis, D.H. Gelfand, J.J. Sninsky \& T.J. White), pp. 315-322. Academic Press, New York.

Wuyts J., De Rijk P., Van de Peer Y., Pison G., Rousseeuw P. \& DE WAChter R. 2000. Comparative analysis of more than 3000 sequences reveals the existence of two pseudoknots in area V4 of eukaryotic small subunit ribosomal RNA. Nucleic Acids Research 28: $4698-4708$.

Zhang J.M., Huss V.A.R., Sun X.P., Chang K.J. \& Pang D.B. 2008. Morphology and phylogenetic position of a trebouxiophycean green alga (Chlorophyta) growing on the rubber tree, Hevea brasiliensis, with the description of a new genus and species. European Journal of Phycology 43: 185-193.

ZuKER M. 2003. Mfold web server for nucleic acid folding and hybridization prediction. Nucleic Acids Research 31: 3406-3415.

ZwICKL D.J. 2006. Genetic algorithm approaches for the phylogenetic analysis of large biological sequence datasets under the maximum likelihood criterion. World-wide electronic publication, The University of Texas, Austin. http://www.bio.utexas.edu/ faculty/antisense/garli/Garli.html (29 January 2013).

Received 9 February 2013; accepted 4 June 2013 